\title{
The Study for the Combination of Scaffolding Instruction and Flipped Classroom Model
}

\author{
Gao Ying* \\ Department of Tourist \\ Hebei Institute of Foreign Language \\ Qinhuangdao China \\ gaoying-huanhuan@163.com
}

\begin{abstract}
This paper mainly researches the combination of scaffolding instruction and flipped classroom model, discuss its applicability. Through the methods of literature review, investigation and practice, this paper analysis the scaffolding instruction theory and flip classroom teaching method systematically and comprehensively, and then discusses the necessity and feasibility of their combination. By extension, this paper puts forward an instructional design method, Three-Two-One instructional design for scaffolding flipped classroom, which consists of three elements (rig scaffolding, complete task, evaluate effect), two stages (tentative study outside the classroom, demonstrate and share in the classroom) and one key (cultivate the ability to solve problems).Finally, this paper studies the application of scaffolding database, for teachers, it provides reference for assign tasks, and for students, it facilitates them to understand knowledge point. Through the study of this paper, it promotes the applications of flipped classroom model, enhances the pertinence of knowledge points, and improves the comprehensive abilities of students.
\end{abstract}

Keywords-scaffolding instruction; flipped classroom model; teaching method; instructional design; scaffolding database

\section{SCAFFOLDING INSTRUCTION AND FLIPPED CLASSROOM MODEL}

Scaffolding instruction is a branch of the constructivist teaching theory, which emphasizes the students as the center, and in the context of collaborative learning. In recent years, more and more educators have been praised, as an important theoretical basis for the reform of education, the study of Scaffolding Teaching as an important part of the construction of teaching concept is becoming mature.

Flipped classroom is to re adjust the time inside and outside the classroom, the decision to learn the right to transfer from the teacher to the students. [1] The dominant ideology and teaching advocated by teachers teaching students to gradually control the dynamic transfer "point of view is agree without prior without previous consultation.

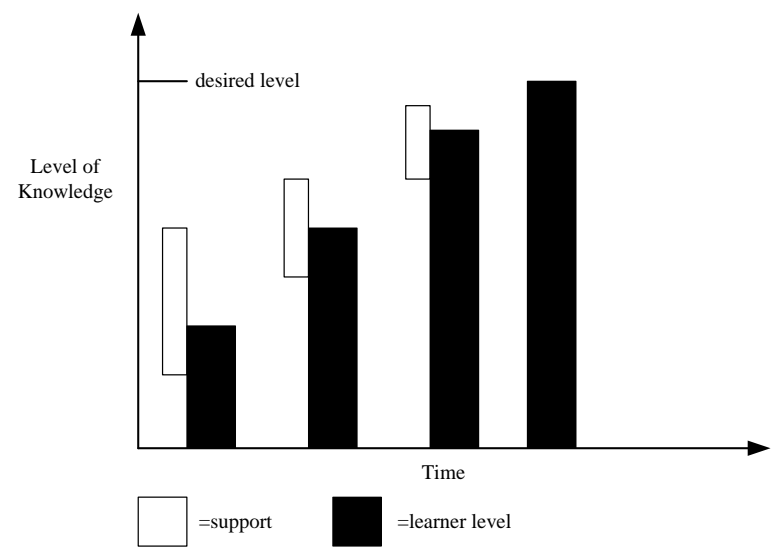

Figure 1. design of scaffolding instruction

\section{THE TEACHING EXPERIMENT OF THE BRACKET TYPE FLIPPED CLASSROOM}

Analysis of students' learning state: To the existing development level of students as the starting point, the target is the student's potential development level. Teachers need to understand the actual level of students' cognition and potentia. [2]First of all, the analysis of students and teaching objectives, build learning support.

The arrangement of scaffolding instruction:To determine the course of study. There is no restriction on the form of the studywith different tasks, different purposes and different purposes. [3]Such as example、 problem 、 suggest 、 guide、 chart. The subjects of this study were Tourism Majors, experiment course is the guide service process. The following form of teaching support:case、problem、suggest、prompt、flow chart,be applied in every link.

Classroom presentation and evaluation: Through selfstudy, students have a certain knowledge of the course content. The method of using real object in class: Teachers will be prepared in advance of the travel agency to send a single, tour guides and other physical distribution into the 
hands of students 。 Suppose you are a tourist guide, Shanghai tour group will take the plane at the airport tomorrow morning at 9 a.m. 。 In the next three days to visit the Imperial Palace, Tiantan, the Badaling Great Wall, the Summer Palace. Live in Holiday Inn. What kind of service is the guide to provide? What problems may arise during the period? How to solve?

Randomly selected several students introduce their design process. The discussion and evaluation by the

Table I. Students self evaluation table

\begin{tabular}{|c|c|c|l|c|}
\hline $\begin{array}{c}\text { Evaluation } \\
\text { items }\end{array}$ & weight & $\begin{array}{c}\text { Evaluation } \\
\text { method }\end{array}$ & Score & $\begin{array}{c}\text { total } \\
\text { points }\end{array}$ \\
\hline $\begin{array}{c}\text { Tourists } \\
\text { complaints } \\
\text { handling }\end{array}$ & 30 & $\begin{array}{c}\text { Self } \\
\text { determination }\end{array}$ & & \\
\hline $\begin{array}{c}\text { Understanding } \\
\text { and standard } \\
\text { service process }\end{array}$ & 20 & $\begin{array}{c}\text { Self } \\
\text { determination }\end{array}$ & & \\
\hline $\begin{array}{c}\text { Master guide } \\
\text { service process }\end{array}$ & 50 & $\begin{array}{c}\text { examination } \\
\text { performance }\end{array}$ & & \\
\hline
\end{tabular}

Teacher evaluation summary of the effect of classroom teaching. Summary of knowledge point. Points out the advantages of students and the problems to be solved.

\section{THREE-TWO-ONE INSTRUCTIONAL DESIGN FOR SCAFFOLDING FLIPPED CLASSROOM}

\section{A. Three elements}

Scaffolding instruction is made up of five main parts: scaffolding, entry situation, independent exploration, cooperative learning and effect evaluation. The practice of applying the scaffolding instruction to the flipped classroom.

\section{1) Build support}

The theme of unit teaching, Teachers should be accurate to know the students' existing knowledge reserve status, To explore the students' recent development zone, follow appropriate standards to build a learning support. To define the "nearest Development Zone" can be understood by the teacher for the students to learn the status of the master, the past test results or the results show and so on, but also through questions, observation, exchange final confirmation. For students' characteristics, teachers should be as far as possible through the support of learning tasks to be decomposed. Allow students to gradually complete the learning tasks in a more relaxed state, and guide them to develop a good self-learning habits and problem-solving skills.

The construction of the scaffold can be divided into two kinds of the design and production. In order to realize the lesson of self prepared and the content is called "the default bracket".[4]Teachers design some learning scaffolds by predicting the level of students, Facilitate the development of students' self study.

In order to guide tourism professional course for example, the characteristics of this course is complicated, the knowledge is fine, have rich practice experience to the mastery of knowledge. In view of the characteristics of this course, it can be designed in advance to help students to sort out the chapter, and design some guides to help teachers and studentsthe most scientific service process, Preparation for work--Service station--Transfer en route-Service to the hotel--The service in the tour--services of dining and shopping and entertainment--Station service-Rehabilitation work.

The evaluation of the learning effect includes students self evaluation and mutual evaluation of students.

Table II. Mutual evaluation of students

\begin{tabular}{|c|l|l|l|l|}
\hline $\begin{array}{c}\text { Evaluation } \\
\text { items }\end{array}$ & \multicolumn{3}{|c|}{ Evaluation results } \\
\hline $\begin{array}{c}\text { Participation } \\
\text { degree }\end{array}$ & excellent & good & average & poor \\
\hline $\begin{array}{c}\text { Cooperative } \\
\text { awareness }\end{array}$ & & & & \\
\hline $\begin{array}{c}\text { Contribution } \\
\text { to collective } \\
\text { results }\end{array}$ & & & & \\
\hline
\end{tabular}

students master the knowledge more convenient; The design of a number of cultural support to help students better understand the knowledge point of the background; The design of some problem bracket helps students to check the effect of self study more effectively.

The design of some examples of support to help students to combine theoretical knowledge and practical application of effective combination. With these specific learning support to guide the students, the students in the course of the flip classroom will become more relaxed, and can better absorb the knowledge of digestion, to complete the learning task. [5]In the classroom teaching, the teacher according to the learning situation and the random design problem or activity is called "build a bracket". Such as the promotion plan, the presentation, the bracket can also play the role of the curriculum connection, is not only the curriculum of the classroom discussion part, but also the next course of the next part of the course. Situational support, such as simulated tour guide on the scene. Bracket type flip classroom teaching itself is also a kind of situational teaching, emphasizing on the establishment of the scaffold in the situation, the tourism profession itself is the requirement of practice, the use of the situation is particularly important. Students in a relatively realistic situation of active participation in the learning activities, you can better understand and use the knowledge point, so that the teaching effect to achieve maximum. Build the frame is the core of the three elements of the link.

\section{2) Solving task}

Difficulties and key points in the implementation of the flipped classroom。 The main body is a student 。In order to help students to overcome the task in time and effectively, the method of cooperative learning can be used. Divide the students into groups, team personnel are not fixed. Members of the constitution should be based on the principle of voluntary, at the same time, consider the level of the students. [6] Is conducive to the exchange of communication skills of the students in this class.Students through group learning, discussion and consultation, sharing resources, mutual learning, deepen understanding 
and the ability of using knowledge, and ultimately overcome the task. The ultimate goal of the flipped classroom teaching is to cultivate students' self-learning habits, improve problem solving skills. Proper layout of tasks to be completed independently, avoid over reliance on other team members. Encourage students to think independently, tap their own potential。Use of various learning resources, such as book information, network information, acquire knowledge and skills.

\section{3) Effect evaluation}

Setting up the evaluation system of the classroom teaching of the bracket type. Evaluation system can be divided into three parts: self-evaluation 、 Mutual evaluation of students 、 Teacher evaluation. Through various evaluation methods to promote students' autonomous learning enthusiasm. [7] Teachers judge students' understanding of the subject of a task, timely adjust task arrangement.

\section{B. Two stages}

Bracket type flip classroom teaching can be divided into two stages. One is to explore the learning stage in the course of. Two is the classroom sharing stage. Most of the teachers and students will be divided into two stages to treat, to explore the learning phase of the course to understand the full delivery to the students to learn the time period, the teacher did not participate in this stage or very little participation. This idea is wrong. Although the ultimate goal of the scaffolding flip classroom teaching is to cultivate students who can study and solve problems independently, but this is a long and difficult process. In a very long time, the students still need the guidance of teachers, so they can not be separated from the course of study.

In the course of sharing stage, it is easy to return to the traditional classroom, strengthen the teacher's role in the unconscious, and weaken the students' participation. In fact, it is a stage for students to perform in class. [8]The teacher should do is to carry out the whole process, put forward questions to guide students to think, to make comments on the task of students, and to organize the students' mutual evaluation. The active participation of students is very important.

Bracket type flipped classroom teaching takes the teacher as the leading, students as the main body, all links are shared by the teachers and students.

\section{A key}

The ultimate goal of the development of the support type flip classroom teaching is to cultivate the students' ability to solve the task. Stimulate students' learning motivation. Cultivate students' self-study habits.Improve classroom interest.Students in the autonomous exploration of thinking, the team to learn from others, in the support of the help of the recent development of the region, to get the level of knowledge use, and ultimately independent of the completion of learning tasks, become the master of learning.

\section{CONCLUSIONS}

In the past, the task driven teaching method is used to arrange the students' learning, the examination can be regarded as a kind of application, but due to the lack of effective guidance, the existence of learning objectives is not strong, the learning effect is poor, students just complete the homework to check, not really understanding of the knowledge system and so on. [9]The reference of the scaffolding teaching method can effectively improve the students' blindness in the process of self study, and provide the guidance to the students' knowledge system and the completion of the task, so that the teaching mode of the flipped classroom is really effective.

Three key links in the development of the frame of the bracket:

\section{A. micro curriculum development}

Flipped classroom is different from the traditional classroom, the curriculum system and the traditional teaching material also has the difference, the curriculum knowledge unit no longer takes the class as the unit, but takes the micro class as the unit, a micro class solves a problem.

The course of turnover is divided into the teaching of knowledge based video tutorials, the reinforcement of knowledge consolidation, and the learning activities for classroom knowledge internalization. The implementation of flipped classroom, combined with the situation of students, subject characteristics and industry needs to develop a problem targeted micro curriculum is very important, is an important factor affecting the success of the flip classroom. [10]As a professional course is taught by different teachers, there are many students in the face of a wide range of students, learning situation, so it is very important to study the support library for the different units of the course.

\section{B. before learning}

In the classroom, the traditional classroom teaching of the teacher led by the teacher is put into the classroom. It is not easy to learn about the knowledge of the students, but through the micro lesson or other media platform, with the help of the study, the new learning content is fully understood the digestion and absorption o Through the study of the knowledge system, skill, practical, the ultimate goal is the effect of the students before the class is not less than the effect of teaching in the classroom, real knowledge internalization. In this complicated process of self study, the function of the learning support library is important. When the students are faced with the bottleneck of self - study, they are learning the support library to search for the appropriate learning clues, hints and keys(which can be regarded as a scaffold). It is convenient for students to study thoroughly before class, and to grasp the basic knowledge comprehensively, and apply the knowledge transfer to the practical problems, The quality of learning before class has a direct impact on the organization of the classroom learning activities of the flipped classroom. The main body is the characteristics of the students, the implementation of the support type flipped classroom is the teacher.

\section{C. classroom activity organization}

The organization of learning activities in the classroom is mainly to help students complete the knowledge of the final, so that students can really use the knowledge to solve problems. Is the most prominent part of the classroom, Is the key to improve the efficiency of teaching and learning. 
Students to participate in classroom activities. Share their learning results. Discuss with the teacher and the students. Make up for their lack of awareness. Deepen the consolidation of the knowledge system, complete the transfer of knowledge to skills. Left the efficient organization of classroom learning activities, flip the classroom will lose its essential characteristics, regardless of how the micro lesson design, how to learn before the lesson, it is difficult to play a good teaching effect of flipped classroom.

In the whole process of the practice of the flip classroom, the existence of the learning support is the key to set the task of teachers, the students to solve the task of the signs, to coordinate the dynamic and the students to study the dynamic consistency of the hub. In the frame of the supporting frame, the relationship between the teacher and the students is the main body. Teachers play a leading role in teaching, is the student learning orientation guide, facilitator and assist to develop the habit of learning learning methods 。Students are the center and the main body of the teaching activities, to set up and adjust the bracket to the students' needs, to encourage students to participate in the whole learning process, with the help of teachers, to promote their own exploration, active learning. In the frame of the support, the relationship between teachers and students is presented. Teachers and students are equal, friendly, cooperative and common progress. Fully mobilize the enthusiasm of teaching and learning two aspects.Make teaching activities more lively, Finally realize the students' initiative study 、 Happy learning、 Lifelong learning.

\section{REFERENCES}

[1] Jonathan Bergmann,Aaron Sams, "Your Classroom-Reach Every Student in Every Class Every Day," [M].Science,2012

[2] Liz Pape,Tracy Sheehan,Collen Worrell, "How to Do More,"[J].Learning\&Learning with Technology,Science,2012

[3] Aaron Sams, Jonathan Bergmann, "Flip Your Students'Learning,"[J]Educational Leadership,Science,2013

[4] Bryan Goodwin and Kirsten Miller, "Evidence on Flipped Classroom is Still Coming In,'[J]. Educationa Leadership, Science, 2013

[5] Maureen J.Lage, Glenn J.Platt, and Michael Treglia, "Inverting the classroom: A Gateway to Creating an Inclusive Learning Enviroment, "[J]. Journal of Economic Education, 2000

[6] Kathleen P.Fulton, “10 reasons to Flip,"[J].New Style of Instruction,2012

[7] Aaron Sams, Jonathan Bergmann, "To Flip or Not Flip?"[J]. Learning \& Leading with Technology,2012

[8] Bill Tucker, "The Flipped Classroom," [J]. Hoover Institution, 2012

[9] Lisa NielsenFive, "Reasons I'm Not Flipping Over The Flipped Classroom,"[J]. Educational Technology Society, 2012

[10] Cheng-Ling Zhao,Feng-Fang Shu,Yi-Chen,A Design and Research on Blended Learning Environment Based on Social Software.[M] Educational Innovation Through Technology(EITT),Science,20 